УДК $101.8 ; 165.2$

DOI 10.18413/2712-746X-2020-44-3-400-410

\title{
Гегель о философской потребности и философская потребность его времени
}

\author{
Иващук О.Ф. \\ Российская академия народного хозяйства и госслужбы при Президенте РФ (РАНХиГС) \\ Россия, Москва, проспект Вернадского, 82-84, строение 2 \\ E-mail: ofi@list.ru
}

\begin{abstract}
Аннотация. Автор анализирует социальный контекст и основные линии полемики того интеллектуального поля, в котором появились первые публикации Гегеля. Социогенетический метод анализа позволяет обосновать гомологии между силами в социально-экономическом пространстве с одной стороны, и в пространстве современной Гегелю интеллектуальной жизни, в котором происходило рождение высших достижений немецкой классической философии, с другой стороны. Формирование мирового рынка и национальных европейских государств в качестве институциональной защиты внутренних локусов товарного производства породило специфические интеллектуальные задачи, успешное решение которых обосновывается в качестве необходимого условия сохранения культуры, открывшейся рынку, и ее успеха в рыночной игре. Гегелевская философия выступает в этом контексте как наиболее релевантный ответ на этот запрос, ответ, ставший существенным моментом цивилизационного прорыва отстающей культуры. В этом и заключалась хорошо осознаваемая им философская потребность его времени.
\end{abstract}

Ключевые слова: ценообразующий рынок, национальное государство, философское поле, гомологии, трансцендентализм, scholastic fallacy, плюриверсум.

Для цитирования: Иващук О.Ф. 2020. Гегель о философской потребности и философская потребность его времени. NOMOTHETIKA: Философия. Социология. Право. 45 (3): 400-410. DOI 10.18413/2712-746X-2020-44-3-400-410

\section{Hegel about the philosophical need and the philosophical need of his time}

\author{
Olga F. Ivashchuk \\ The Russian Presidential Academy of National Economy and Public Administration (RANEPA) \\ Building 2, 82-84, Vernadsky prospect, Moscow, Rucssia \\ E-mail: ofi@list.ru
}

\begin{abstract}
The author analyzes the social context and main lines of polemics of the intellectual field in which Hegel's first publication appeared. The sociogenetic method of analysis allows us to establish homologies between forces in social and economic space, on the one hand, and, on the other hand, in the space of contemporary to Hegel intellectual life, where the highest achievements of German classical philosophy were born. The formation of the world market and national European states as the institutional protection of the internal loci of commodity production gave rise to specific intellectual tasks, the successful solution of which is substantiated as an essential component of the preservation of the culture that opened the market and its success in the market game. Hegelian philosophy, starting with his first significant publications, appears in this context as the most relevant response to this request, the response which has become an essential moment of the civilizational breakthrough of a lagging culture. That was namely the well-understood by him philosophical need of his time.
\end{abstract}

Key words: pricing market, nation state, philosophical field, homology, transcendentalism, scholastic fallacy, pluriversum. 
For citation: Ivashchuk O.F. 2020. Hegel about the philosophical need and the philosophical need of his time. NOMOTHETIKA: Philosophy. Sociology. Law series. 45 (3): 400-410 (in Russian). DOI 10.18413 /2712-746X-2020-44-3-400-410

\section{Введение}

Вероятно, не было во всей истории философии такого мыслителя, наследие которого вызывало бы столь противоречивое к себе отношение, как Гегель, который неизменно притягивал толкователей противоположных направлений. Что-то такое он «выпустил из несуществования» [Хайдеггер, 1993а, с. 224], став «виновником» «раскрытия потаенности», которое ему вменяется весьма многообразными способами. Среди этих способов есть жесткие обвинения в самом узком смысле, и порой чем больше Гегель притягивал, тем резче звучали обвинения в его адрес. Поскольку, как показал Хайдеггер, именно в том, что сильнее всего «задевает», следует искать входа «внутрь» философии [Хайдеггер, 1993б, с. 113], то мы и попытаемся дать анализ того, что Гегелю предъявлено наиболее враждебной критикой, и сделать это началом путеводной нити, которая приведет нас к пониманию того, в чем состояла потребность, породившая гегелевскую философию, и того, как он сам понимал «философскую потребность» [Hegel 1981, p. 24] ${ }^{1}$, на которую отвечал.

\section{В чем провинился Гегель?}

Весь спектр упреков, высказанных в разное время в адрес Гегеля, вероятно, невозможно охватить в статье, но он, как показывает В. Серф [Serf, 1977], с которым мы в этом солидарны, размещается между двумя полюсами, и их здесь можно кратко обрисовать. Это, с одной стороны, аналитически и сциентистски ориентированная философия, которая отвергла идею логики нового типа, с другой стороны - ее известный антипод, антисциентистски ориентированная экзистенциальная философия.

Образец критики первого типа - К. Поппер. Он обвиняет Гегеля в том, что тот, опираясь на тождество противоположностей, обосновывает такой коллективизм, который поглощает человеческую индивидуальность, подчиняет ее тотальности государства, «платным агентом» которого выступает рвущийся к власти Гегель [Поппер, 1992, с. 43]. Образец критики второго типа среди наиболее бескомпромиссных вариантов мы находим, например, у Э. Фёгеллина. Здесь гегелевское тождество выступает как притязание примирить извечную разорванность человеческой экзистенции (покушаться на эту разорванность все равно что «уничтожать гуманистичность человека») [Фёгелин, 1973, с. 80], а выдвигающий его Гегель выдает себя за нового Мессию и с помощью магических заклинаний «намеревается достичь господства как колдун, который будет заклинать идола истории - видимость, дух - с целью заслонить историю, творимую Богом» [Фёгелин, 1973, с. 78].

При всей несхожести отправных позиций этой критики, структурное сходство обвинений очевидно: Гегель стремится к власти (политической и / или религиозномессианской) и для этого хочет выдать чародейство / мистику (которую изобличает самопротиворечивость его построений) за науку, приписывая человеку и его мышлению завышенные возможности: возможность логически мыслить, нарушая закон запрета противоречия, или возможность соединить несоединимое с помощью противоречия, объявленного законом высшей логики. Таким образом, главным предметом критики является гегелев-

${ }^{1}$ Удивительным образом параграф «Философская потребность» отсутствует в русском переводе гегелевского эссе «Различие между системами философии Фихте и Шеллинга в соотнесении с работами Рейнгольда, имевшими целью облегчить обзор состояния философии в начале 19го столетия» [Гегель, 1988]. 
ское развенчание запрета противоречия как высшей логической формы, которое толкуется как подтасовка, мотивированная стремлением к власти.

Попытки проверить состоятельность этой обвинительной конструкции многочисленны и свидетельствуют не в ее пользу. С одной стороны, сама внутренняя эволюция аналитической философии оборачивается в XX веке удивительным результатом: разрабатывая свои теоретические проблемы, аналитическая философия обнаружила себя конвергирующей с гегельянством [Giladi, 1917; Redding, 2010; Redding, 2019]. И это значит, она развивалась в русле логики, обоснованной Гегелем, в предсказанном им направлении, и она сама обнаружила это, достигнув достаточной зрелости.

Существуют и скрупулезные исследования гегелевских текстов, специально направленные на проверку предположений К. Поппера и других об авторитаризме гегелевской философии. Они показывают, что авторитаризм не имеет ничего общего ни с политическими симпатиями Гегеля, ни с его теоретическими импликациями [Baumann, 2018].

Тем не менее, обрисованные установки сохраняются в сообществе в качестве само собой разумеющегося положения дел. И такая - патовая - ситуация указывает, что здесь требуется анализ особого типа, который способен поставить под вопрос данный паттерн «само собой разумеющегося», выявить и нейтрализовать то, что превращает его в молчаливо принимаемую и устойчиво воспроизводимую господствующую установку. Всякий механизм навязывания каких-то диспозиций, в том числе теоретических, в качестве квазиприродных, естественных, единственно возможных, является и механизмом вытеснения иного способа мыслить. Поэтому анализ, чтобы вскрыть эти механизмы и восстановить изжитые ими возможности, должен быть социогенетическим [Бурдье, 2016]. Нижеследующее представляет собой попытку такового.

\section{Социогенетический анализ гегелевской философии}

\section{А) В какой философии нуждалась Германия начала ХІХ века?}

Чтобы представить себе обстоятельства, в которых рождалась гегелевская философия, эта сложная до странности «интеллектуальная акробатика», достаточно вспомнить, что к этому времени английские bourgeois уж примерно полтора века двигали свою страну по пути активного промышленного и рыночного развития, французские citoyens более десяти лет назад совершили свою Великую революцию, а ставший консулом Наполеон стремился обеспечить французской промышленной и финансовой буржуазии первенство на европейском рынке, проводя в стране реформы, закреплявшие завоевания революции. Германия ко времени вторжения Наполеона в германские земли (1892 г) все еще оставалась задворками Европы и оказалась слишком слабой и административно, и экономически даже для того, чтобы оказать сопротивление французской оккупации. Ее землевладельцы уже не были в силах воспроизвести себя и свой образ жизни и вынуждены были перезакладывать имения и искать государственной службы для прожитка.

Достаточно представительной фигурой юнкера тех лет был барон Г. фон Штайн [Каринский, 1903], который обучался юриспруденциии и изучал английскую историю в Геттингене. Нужда в средствах для жизни побудила его искать пути реформирования текущей ситуации, а знатность рода позволила занять достаточно высокое административное положение, чтобы последовательно и успешно бороться за осуществление своих замыслов. В число последних входило освобождение крестьян от крепостной зависимости, наделение их землей, разделение общинных земель и государственная охрана прав собственников, налоговая реформа, способствующая формированию внутреннего рынка и институционально защищенного рыночного производства.

Рыночное производство в Европе к концу XVIII в. уже достигло таких масштабов, что ему не существовало альтернатив: каждая культура, вступающая в контакт со странами, уже направившимися по индустриально-капиталистическому пути, просто вынуждена 
была, чтобы вообще сохраниться, специфический для нее способ производства человека переплавить в рыночный. Так возникает всемирный рынок современного типа, рынок laissez-faire. Это прежде всего означает коммодификацию всех факторов производства (в том числе тех, которые К. Поланьи называет «фиктивными товарами» [Поланьи 2007, c. 87] - это деньги, труд и земля, а К. Маркс - моментами производственного отношения: субъектом-организатором общественного производства (который зависит от стоимости денег), субъектом-непосредственным производителем (собственником рабочей силы) и природой [Маркс 1962, с. 354]). Сможет ли при этом рынок функционировать производительно или произойдет удушение производства (и субъектности культуры) рынком - зависит от того, защищают ли культурные институции от буквализма коммодификации самих субъектов производственного отношения, позволяя им воспроизводиться.

Как показывает исторический опыт, наиболее эффективным интегратором всех трех направлений защиты воспроизводства является национальное бюрократическое (не династическое) государство, поэтому такое государство и рынок возникают одновременно и друг без друга невозможны. При этом типической особенностью трансформаций такого рода является то, что представители уходящего уклада играют в них характерную роль: они, сопротивляясь развертыванию рыночно-городских процессов, пытаются организовать защиты собственных позиций и населения с помощью социальных мер, наподобие «хлебных законов» в Англии. Такие процессы амбивалентны, поскольку, с одной стороны, помогают выжить беднейшим, замедляя слишком стремительный подрыв их жизненных условий, с другой - не дают им достойно заработать на жизнь, вызывая деградацию и инфантилизацию населения и производственный коллапс. Парадигматическим примером таких консервативных защит является описанный К. Поланьи Спинхемлэнд [Поланьи 1992].

Фридрих Вильгельм III, прусский король, призвавший к себе Г. фон Штайна в качестве премьер-министра, хотя периодически и отправлял его в отставку за реформаторскую отвагу, все же был вынужден под давлением международной конкуренции, в особенности со стороны Франции, оккупировавшей почти всю Германию, следовать советам Штайна. Видимо, только угроза полной потери суверенитета вынудила его принять позицию Штайна и сдвинуть баланс противостояния в пользу набравшей уже обороты и принявшей военную форму межнациональной рыночной конкуренции против изживших себя и тормозящих выработку адекватных ответов на эти вызовы сил, связанных с ретроградными, сеньориальными, спинхемлэнд-тенденциями. В итоге в 1807 г. указ об отмене крепостного права был утвержден, причем, по настоянию Штайна, для всей территории государства, а не для востока Пруссии, как планировали первоначально. Так, шаг за шагом, Пруссия, которая начала создавать себе пространство интенсивного капиталистического развития, становилась надеждой всех немцев.

При этом Германия не просто отдала себя на милость носителей прогресса: так она бы только позволила себя колонизировать. Даже самые прогрессивно, либерально и франкофильски настроенные немцы (кто, подобно Гегелю или Бетховену видел в Наполеоне героя) быстро убедились, что въезд в страну этой идеи мировой истории на белом коне ничего, кроме расстройства жизни и подчинения завоеванной страны, не несет, и что единственный способ быть на высоте прогресса - не принять подчиненный статус, а найти способ противостоять господству. Без превращения собственного государства в орудие реформ это было бы невозможно.

Но сделать это было непросто, поскольку надлежало уйти и от Сциллы сеньориального и спинхемлэнд-ориентированного мышления, которое было исходным у тех, кто имел доступ к ключевым формирующим позициям, и от Харибды прямого взаимодействия с развитым рынком.

Так Германия и нащупывала оптимальный в сложившихся условиях путь успешного выхода на мировой рынок в качестве притязающего на равенство игрока. 
Оптимальной стратегией борьбы в данных условиях является попытка не просто занять место сильного (это невозможно), но оспорить сам порядок мира с единственным центром господства в пользу плюриверсального [Элиас, 2001]. Это позволяет противодействовать унифицирующим стратегиям, которые пытается навязать лидер рынка, и приводит к возникновению в сознании сопротивляющейся культуры различия цивилизации как чужой, формальной, формы, олицетворяемой лидером (экспансии которого выгодна сдвигаемая или открытая граница), и культуры, т.е. формы, выросшей на собственной почве (eigentlich) и имеющей свою четкую границу и особенность.

Экспансия лидера стремится навязать культурно-безотносительный, т.е. индивидуалистический, образ мыслей и подчиняемым, поскольку принятие соперником этих правил игры лишает его символических опор для выработки коллективного сопротивления и делает легитимным выигрыш лидера. Точкой зрения господства, как показывает П.Бурдье, вообще является точка зрения одиночного Cogito [Бурдье, 2001], поскольку она содержит трудно выявляемую ошибку, которую П. Бурдье называет scholastic fallacy. Последняя состоит в том, что сеньориально настроенный теоретик, располагающий досугом, приписывает то же состояние и свои интересы тем, кто погружен в недосуг [Бурдье 2019]. Она и является инструментом навязывания определенных форм мышления и поведения - тех, которые поддерживают господство единственного субъекта, объективируя всех остальных. Это непризнание субъективности других достигается вытеснением из зоны видимости альтернативных способов vision et division, тем самым актуальное господство легитимируется, превращается в «естественное», а способы его оспорить - в недоступные.

Вот почему плоско-эмпирическое воззрение на мир и науку, связанное с точкой зрения одинокого индивида, возобладало в английском и французском Просвещении, представителю которого трудно было бы даже объяснить, в чем различие цивилизации и культуры, но в немецкой культуре оценивалось как если и неизбежное, то все же сугубо вторичное и опосредствованное, что надо обезвредить, чтобы «из смерти и заката ложной науки и абстрактных теорий в Германии могла скорее прорасти истинная Наука и Метафизика» [Шеллинг, 2009, с. 465].

Описанные процессы радикального переустройства, смены основания социального развития и были той волшебной ретортой, в которой родилась «потребность в философии», а затем и сама эта невиданная и ставшая мировой вершиной философия, которой в символической борьбе и надлежало преодолеть scholastic fallacy, чтобы вооружить свою культуру одновременно не только против рыночно-цивилизационной экспансии, но и против того, что В. Зомбарт называет сеньориальным образом мыслей [Зомбарт 2005, с. 37, 147 и далее], которой надлежало оказывать этому образу мыслей систематическое противодействие ${ }^{1}$, культивируя предпринимательский, инновативный дух.

Самостоятельная продуктивность, свобода творческой субъективности, ее условия возможности - вот что должно было выдвинуться на первый план в духовной жизни. Причем условия эти отыскивались не только в ментальном пространстве одинокого субъекта, но и в пространстве межсубъективном, социально-институциональном.

\section{Б) Гегелевский ответ на философскую потребность}

Первым шагом к институциональным преобразованиям в описанном направлении было развертывание Cogito в трансцендентальную субъективность. Но от Cogito еe отличает только абстрактно-всеобщий характер, при котором сверхиндивидуальные характеристики человека моделируются все же по образу индивида («яйность» вместо «я»). Поэтому есть все основания квалифицировать ее, как это делает и П. Бурдье [2019, с. 294],

\footnotetext{
1 «Что всегда сокрушало предпринимательский дух, без которого не может существовать дух капиталистический, - это измельчание в сытое рантьерство или усвоение сеньориальных замашек» [Зомбарт 2005, с. 434].
} 
как разновидность scholastic fallacy. Чтобы отличить ее от первой, наивной версии, Бурдье вслед за американской социологией называет их как RAT (rational activity theory) и CAT (collective activity theory).

В обеих версиях cogito-ориентированная организация человеческого мира превращает его в процесс по преимуществу познавательно детерминированный, где одинокому мыслящему индивиду, умеющему «пользоваться собственным умом» [Кант 1966, с. 27], может противостоять и им признаваться лишь полагаемый им объект, в котором все исчислимо, и теория, помимо такого исчисления, не видит за собой иных возможностей и обязанностей, вытесняя все прочее в область веры. О вере и знании Гегель будет рассуждать в работе, которая так и называется, «Вера и знание», и которая была второй по счету публикацией Гегеля в «Критическом журнале философии», который они издавали вдвоем с Шеллингом.

Но каким же должно быть надлежащее, соответствующее вызовам времени, решение проблемы соотношения субъекта и объекта? На уяснение этого, прежде всего самому себе, была направлена уже самая первая крупная публикация в этом же журнале - эссе «Различия философских систем Фихте и Шеллинга». И здесь очевидно, что для Гегеля, как и для всей его культуры, углубление в этот по виду отвлеченно гносеологический вопрос имеет прямое экзистенциальное значение, как вопрос выживания, ведь «философия порождается своим временем... только для того, чтобы вопреки разрушениям века восстановить человека из себя» [Гегель, 1990, с. 146].

Субъект-объектное отношение в сознании самих теоретиков этого времени является прежде всего проблемой контроля господства и правильной организации межиндивидуальных связей. И Гегель, взявшись решать эту проблему, стремится обосновать такую общность, где обе противоположности были бы равно реальными, что означает: чтобы объект мог переходить в субъект [Гегель, 1989, с. 131], в противном случае свобода и самоопределяемость господствующего субъекта оказываются лишь иллюзией и неявным дуализмом, зависимостью от неизвестного и произволом [Гегель, 1989, с. 129].

Разум, конечно, «может попытаться решить проблему так, что одно он уничтожает, одну из противоположностей, а другую возводит в бесконечность. Это, по сути, и произошло в Фихтевой системе», поскольку «В трансцендентальном «Я = Я» ... одно является господствующим, другое - подчиненным, субъективное не равно объективному, а оба находятся в каузальном отношении. Одно оказывается зависимым, из двух сфер, свободы и необходимости, последняя подчинена первой. Таким образом, конец системы не отвечает своему началу» [Гегель, 1989, с. 143].

В итоге у Фихте мы имеем конструкцию полицейского государства, «государства бедствования (Notstaat)» [Гегель, 1989, с. 149], в котором «полиция довольно точно знает, где находится каждый ее гражданин в любое время дня и чем занимается» [Гегель 1989, c. 150]. Но «такой способ сохраняет противоположность, ибо то, что полагается как абсолютное, обусловливается другим, и пока существует одно, существует и другое» [Гегель 1988, c. 128].

Напротив, разумно устроенная «общность личности с другими должна рассматриваться поэтому существенно не как ограничение истинной свободы индивидуума, а как ее расширение. Самая высшая общность есть высшая свобода как власти, так и ее исполнения, - но именно в этой высшей общности как раз свобода как идеальный фактор и разум как противоположность природы совершенно отпадают» [Гегель 1989, с. 148]. Под идеальным фактором здесь имеется в виду свобода на стороне господства, чистого мышления Я = Я, а противоположность разума и природы возникает, когда «живое разрывается на понятие и материю и природа попадает в зависимость» [Гегель 1989, с. 148]. Такое «поношение» природы, в том числе нашей собственной, претит Гегелю с эстетической точки зрения, но он и сам понимает, что на шеллингианский манер выразить «презрение» этой 
«рассудочной сущности господства» [Гегель 1989, с. 156] совершенно недостаточно. Необходимо идти дальше шеллингианского инструментария борьбы с нею.

Поэтому в следующей большой публикации, появившейся годом позже, в «Вере и знании» Гегель берется не просто за описание недостатков неудовлетворительного состояния умов, но, выделив фихтеанский трансценденталистский принцип как высшее напряжение «потребности в философии», как некий предел, «в рамках» которого «все остались... и не могли ему противостоять» [Гегель 1988, с. 152], и сделав его преодоление задачей, он прослеживает генезис этого принципа, узловые моменты которого он находит как противоположности, каковыми последовательно выступают учения Канта и Якоби. Их отчетливо проявленный характер экстремумов и противоположностей по отношению друг к другу позволяет ему заключить, что этот принцип имеет тенденцию преодоления себя самого изнутри и что он, реализовав свои предельно противоположные возможности, тем самым исчерпал их все и подготовил переход к более высокой и сложной жизненной форме.

\section{Гегель, трансцендентализм и социоэкономическое поле:} гомологии

Насколько такой поиск сложностей был насущным, можно попытаться понять, проведя гомологии между жизнью «узкого срединного слоя... без социального фундамента» (поскольку восхождение буржуазии к благосостоянию «в это время только начинается» [Элиас 2001, с. 83]), и тем, как его представители выражают и обосновывают свои устремления. Чтобы эти гомологии усмотреть, надо принять во внимание замечание Н. Элиаса: «Для сознания среднего сословия нет ничего более характерного, чем это выражение: "Двери на лестницу, ведущую вниз, должны оставаться закрытыми". Открыться должен путь наверх. Как и любой слой, находящийся посередине, этот слой оказывается в своего рода ловушке: он не может желать разрушения стен, мешающих ему подняться вверх, из страха, что падут и стены, отделяющие его от народа» [Элиас 2001, с. 74].

Наилучшим способом занять это срединное положение в символическом поле является тот именно принцип, с которым с первых же публикаций развернул борьбу Гегель, т.е. трансцендентализм: его достаточно, чтобы отграничить достоинство своей «культуры» от поверхностности аристократической «сіvilité», но недостаточно, брататься с низами, он, как и Bildung, который отсутствует равно у общеевропейской аристократии, и у трудящихся слоев, является «паролем узкого срединного слоя» [Элиас 2001, с. 83]. Возвышаясь над здравым смыслом, он держит закрытой дверь вниз. Но этот баланс, при всей характерной для немецкой специфики непроницаемости аристократического класса, создающей, казалось бы, большее напряжение между ним и восходящей буржуазией, чем между нею и низшими слоями, все же всегда создает искушение закрепиться (лучше априори) на месте сильного.

Таким образом, дистанцируясь от трансцендентализма и требуя преодоления установки однополярного господства, Гегель занимает наиболее левую позицию из возникших альтернатив. В 1802 году он ищет условий возможности пробиться к другому субъекту объективным средствами. А к 1807 году в «Феноменологии духа» построит для него - для всех как обязательную - образовательную лестницу.

Выше мы показали, что искушение занять единственный полюс господства является сеньориальным стремлением и предпосылкой легитимации действующих в одном направлении спинхемлэнд-образных и колонизирующих, то есть опасных, парализующих локальное производство, тенденций. Видимо, поэтому зайти так далеко, даже просто в 
мысли, в направлении демократизации культуры, как Гегель, культуре дано не в любую эпоху, а только когда сеньориальные тенденции немедленно ставят ее перед лицом краха.

\section{Заключение}

Вот мы и нашли, в чем провинился Гегель: отвечая на потребность в такой философии, которая позволит консолидировать усилия культуры в направлении и защиты своей продуктивности, он распахнул ту самую дверь, которую старательно подпирали за собой стремящиеся институционально закрепить собственное господство его достигшие респектабельности современники и сегодняшние их потомки. Разоблачение трансцендентализма как ущербной доктрины выдает «самую тайную и самую общеизвестную из тайн (ведь ее охраной заняты все)» [Бурдье 2001, с. 224], разрушает «институционально организованное и гарантированное неузнавание» [Бурдье 2001, с. 119] стремления восходящего класса к господству сеньориального типа, дорогостоящую коллективную работу по отладке легитимирующего это стремление символического оружия. Образовательная лестница наверх, которую Гегель, начиная с первых работ, устраивал для всех субъектов, оказавшихся внизу, угрожает самой структуре господства сеньориально-мандаринского типа, в которой институционально закреплено признание одного-единственного субъекта - господствующего. Сама сохранность этой структуры зависит от демонтажа или хотя бы сокрытия этой лестницы.

Лучший прием нейтрализации последствий гегелевских открытий в символической борьбе для хорошо институциализированных мандаринов - критиковать Гегеля за свои собственные прегрешения. Именно это мы и наблюдаем на обоих полюсах критики. Так, Поппер критикует поглощение индивида коллективной тотальностью, но ведь реальной мишенью этой критики является как раз трансценденталистская установка, САТ-разновидность scholastic fallacy, которую разделяет как раз Поппер, но не Гегель. В ней индивид действительно поглощен обществом, объективирован, нивелирован, потому что общество само является трансцендентальным и одиноким субъектом-супериндивидом. И то же верно для Фёгеллина, который, кипя возмущением, описывает... себя: колдовство воображения, которому надлежит оставаться тайной, и создание фиктивного «мира феноменов», как и эстетических фикций способности суждения, - это по части вполне классического трансцендентализма кантовского образца, но не гегелевской имманентной предмету методологии, которая с помощью противоречия «снимает» или, на языке П. Бурдье, «объективирует» объективацию, полагая свой предмет как субъект и плюриверсум субъектов.

\section{Список источников}

1. Гегель Г.В.Ф. 1988. Различие между системами философии Фихте и Шеллинга в соотнесении с работами Рейнгольда, имевшими целью облегчить обзор состояния философии в начале 19-го столетия. Пер с нем. КАНТОВСКИЙ СБОРНИК. Межвузовский тематический сборник научных трудов. Вып. 13, с. 148-174. (Hegel G.W.F. 1801. Differenz des Fichteschen und Schellingschen Systems der Philosophie in Beziehung auf Reinholds Beytrage zur leichtern Obersicht des Zustands der Philosophie zu Anfang des neunzehnten jahrhunderts. Jena, Akademische Buchhandlung 1801).

2. Кант И. 1966. Ответ на вопрос: что такое Просвещение? Пер. с нем. Кант И. Соч.: в 6 т. T. 6. М., Мысль. 743 с. (Kant I. 1784. Beantwortung der Frage: Was ist Aufklärung? Berlinische Monthly 4 (1784), pp. 481-494)

3. Каринский Д.Д. 1890-1907. Штейн, Генрих-Фридрих-Карл. Энциклопедический словарь Брокгауза и Ефрона, в 86 т. (82 т. и 4 доп.). СПб.

4. Маркс К. 1962. Капитал. Книга III: Процесс капиталистического производства, взятый в целом. Часть 2. Пер с нем. Маркс К. Энгельс Ф. Соч. 2-е изд. Т. 25 Ч. 2. М.: Гос. изд-во политической литературы, 552 с. (Marx K. 1894. Das Kapital. Kritik der politischen Ökonomie. Band 3: Der Gesamtprozess der kapitalistischen Produktion. Hrsg. von Engels, Marx-Engels-Werke, Band 25) 
5. Шеллинг Ф.В.Й. 2009. О сущности немецкой науки. Пер. с нем. Отрывок из фрагмента незаконченной статьи Шеллинга «О сущности немецкой науки», 1807. И.Л. Фокин. Philosophus Teutonicus. Якоб Бёме: возвещение и путь немецкого идеализма. СПб., 2014. Приложение, 461-477. (Schelling F.W.J.1807. Uber das Wesen deutscher Wissenschaft. Aus dem handschriftlichen Nachlass 1807)

\section{Список литературы}

1. Бурдье П. 2016. О государстве. Курс лекций в Коллеж де Франс (1989-1992). Пер с франц. М., Дело. 720 с. (Bourdieu P. 2012. Sur l'État. Cours au Collège de France (1989-1992). Raisons d'AGIR \Seuil).

2. Бурдье П. 2001 г. Практический смысл. Пер с франц. СПб., Алетейя, 562 с. (Bourdieu P. 1980. Le Sens pratique. Les Éditions de Minuit, Paris).

3. Бурдье П. 2019. Экономическая антропология. Курс лекций в Коллеж де Франс (19921993). Пер с франц. М., Изд. дом Дело РАНХиГС. 416 с (Bourdieu Р. 2017. Anthropologie économique. Cours au Collège de France 1992-1993. Raisons d'AGIR ISeuil)

4. Зомбарт В. 2005. Буржуа. К истории духовного развития современного экономического человека. Пер с нем. Санкт-Петербург, «ВЛАДИМИР ДАЛЬ». 639 с. (Sombart, Werner. 1913. Der Bourgeois. München und Leipzig: Duncker \& Humblot)

5. Поланьи К. 2002. Великая трансформация: политические и экономические истоки нашего времени. Пер. с англ. СПб., Алетейя. 320 с. (Polanyi, К. 1944. The Great Transformation: The Political and Economic Origins of Our Time. New York: Farrar \& Rinehart)

6. Поланьи К. 2007. О вере в экономический детерминизм. В кн.: «Великая трансформация» Карла Поланьи: прошлое, настоящее, будущее. Под общей ред. Р.М. Нуреева. Пер. с англ. М., ГУ-ВШЭ. 321c. (Polanyi K. 1947. On Belief inEconomic Determinism. Sociological Review, vol. 37, no. 1, pp. 96-112)

7. Поппер К. 1992. Открытое общество и его враги. Т. 2: Время лжепророков: Гегель, Маркс и другие оракулы. Пер. с англ. М., Феникс, Международный фонд «Культурная инициатива». 528 с. (Popper K.R. 1966. The Open Society And Its Enemy. Vol. 2. ROUTLEDGE and KEGAN PAUL London and Heniey)

8. Фегелин Э. 1973. О Гегеле - исследование чародейства. Отрывки из доклада на Первой Конференции Международного общества Изучения Времени, Обервольфах, 31 августа - 6 сентября 1969 года. Пер. с нем. ВОЛЬНОЕ СЛОВО Самиздат. Избранное. Документальная серия. Выпуск 9-10. ВЕЧЕ № 5. (Vögelin E. 1971. On Hegel - A Study in Sorcery. Studium Generale. Vol. 24 (1971), pp. 335-368)

9. Хайдеггер М. 1993. Вопрос о технике. Пер. с нем. В кн.: Хайдеггер М. Время и бытие. М., Республика, 447 с (Heidegger M. 1954. Die Frage nach der Technik// Die Künste im Technischen Zeitalter. München, Oldenbourg. pp.70-108).

10. Хайдеггер М. 1993. Что такое философия? Пер. с нем. // Вопросы философии. № 8. c.113-123. (Heidegger M. 1956. Was ist das - die Philosophie? Verlag Günter Neske, Pfulingen)

11. Элиас Н. 2001. О процессе цивилизации. Социогенетические и психогенетические исследования. Том 1. Изменения в поведении высшего слоя мирян в странах запада. Пер. с нем. СПб., Университетская книга, 336 с. (Elias N. 1939. Über den Prozeß der Zivilisation. Soziogenetische und psychogenetische Untersuchungen. Bd. 1: Wandlungen des Verhaltens in den westlichen Oberschichten des Abendlandes. Basel, Haus zum Falken).

12. Baumann Ch. 2018. Was Hegel an Authoritarian Thinker? Reading Hegel's Philosophy of History on the Basis of his Metaphysics. Forthcoming in Archiv für Geschichte der Philosophie Vol. 2, 2021. (Submitted 11/2017; accepted for publication 9/2018). URL: https://www.academia.edu /38305339/Was Hegel an Authoritarian Thinker Reading Hegels Philosophy of History on the Bas is of his Metaphysics (Accessed 18 of June) 185-198

13. Giladi P. 2017. Hegel, Analytic Philosophy’s Pharmakon. The European Legacy, 22:2,

14. Hegel G.W.F. 1981. Differenz des Fichteschen und Schellingschen Systems der Philosophie in Beziehung auf Reinholds Beytrage zur leichtern Obersicht des Zustands der Philosophie zu Anfang des neunzehnten jahrhunderts. Verlag Philipp Reclam jun. Lepzig 
15. Redding Paul. 2010. The Possibility of German Idealism after Analytic Philosophy: McDowell, Brandom and Beyond. Postanalytic and Metacontinental: Crossing Philosophical Divides, ed. Jack Reinolds et al. New York: Continuum, 191-202

16. Redding Paul. 2019. Rethinking Sellars' Myth of the Given: From the Epistemological to the Modal Relevance of Givenness in Kant and Hegel. International Journal of Philosophical Studies. Volume 27, 2019 - Issue 3: Hegel and Sellars. pp. 379-398

17. Serf W. 1977. Speculative Philosophy and Intellectual Intuition. An Introduction to Hegel's Essays. Hegel G.W.F. Faith \& Knowledge. Translated by W. Serf and H.S. Harris. State University of New York Press, Albany

\section{References}

1. Burd'e P. 2016. O gosudarstve. Kurs lektsii v Kollezh de Frans (1989-1992). [About the state. Course of lectures at the Collège de France (1989-1992)]. Translated from the French. M., Delo. 720 p. (Bourdieu P. 2012. Sur l'État. Cours au Collège de France (1989-1992). Raisons d'AGIR ISeuil).

2. Burd'e P. 2001 g. Prakticheskii smysl. [Practical sense]. Translated from the French. SPb., Aleteiya, 562 p. (Bour-dieu P. 1980. Le Sens pratique. Les Éditions de Minuit, Paris).

3. Burd'e P. 2019. Ekonomicheskaya antropologiya. Kurs lektsii v Kollezh de Frans (19921993). [Economic anthropology. Course of lectures at the Collège de France (1992-1993)]. Translated from the French. M., Izd. dom Delo RANKhiGS. 416 s (Bourdieu P. 2017. Anthropolo-gie économique. Cours au Collège de France 1992-1993. Raisons d’AGIR ISeuil)

4. Zombart V. 2005. Burzhua. K istorii dukhovnogo razvitiya sovremennogo ekonomicheskogo cheloveka. [Bourgeois. On the history of the spiritual development of modern economic man]. Translation from German. Sankt-Peterburg, «VLADIMIR DAL"». 639 p. (Sombart, Werner. 1913. Der Bourgeois. München und Leipzig: Duncker \& Humblot)

5. Polan'i K. 2002. Velikaya transformatsiya: politicheskie i ekonomicheskie istoki nashego vremeni. [The great transformation: the political and economic origins of our time]. Translated from English. SPb., Aleteiya. 320 p. (Polanyi, K. 1944. The Great Transfor-mation: The Political and Economic Origins of Our Time. New York: Farrar \& Rinehart)

6. Polan'i K. 2007. O vere $\mathrm{v}$ ekonomicheskii determinizm [On the belief in economic determinism]. In: «Velikaya transformatsiya» Karla Polan'i: proshloe, nastoyashchee, budushchee ["The great transformation" by Karl Polanyi: past, present, future]. Ed. R.M. Nureeva. M., GU-VShE. 321 p. (Polanyi K. 1947. On Belief inEconomic Determinism. Sociological Re-view, vol. 37, no. 1, pp. 96-112)

7. Popper K. 1992. Otkrytoe obshchestvo i ego vragi. Vol. 2: Vremya lzheprorokov: Gegel', Marks i drugie orakuly. [Open society and its enemies, Vol. 2: The time of false prophets: Gegel, Marx and other oracles]. Translated from English. M., Feniks, Mezhdunarodnyi fond «Kul'turnaya initsiativa». 528 p. (Popper K.R. 1966. The Open Society And Its Enemy. Vol. 2. ROUTLEDGE and KEGAN PAUL London and Heniey)

8. Fegelin E. 1973. O Gegele - issledovanie charodeistva. [On Hegel - a study of witchcraft]. Excerpts from a report at the First Conference of the International society for the Study of Time, Oberwolfach, 31 Aug-6 September 1969. Translation from German. VOL"NOE SLOVO Samizdat. Favourites. Documentary series. Issue 9-10. VEChE № 5 (Vögelin E. 1971. On Hegel — A Study in Sorcery. Studium Generale. Vol. 24 (1971), pp. 335-368)

9. Khaidegger M. 1993. Vopros o tekhnike. [Question about technology]. In: V kn.: Vremya i bytie. [Time and being: articles and speeches]. Translation from German. M., Respublika, $447 \mathrm{p}$ (Heidegger M. 1954. Die Frage nach der Technik. Die Künste im Technischen Zeitalter. München, Oldenbourg. rr.70-108).

10. Khaidegger M. 1993. Chto takoe filosofiya? [What is philosophy?] Translation from German. Voprosy filosofii, 8: 113-123. (Heidegger M. 1956. Was ist das - die Philosophie? Verlag Günter Neske, Pfulingen)

11. Elias N. 2001. O protsesse tsivilizatsii. Sotsiogeneticheskie i psikhogeneticheskie issledovaniya. Tom 1. Izmeneniya v povedenii vysshego sloya miryan $\mathrm{v}$ stranakh zapada. [About the process of civilization. Sociogenetic and psychogenetic research. Vol. 1. Changes in the behavior of the upper layer of the laity in the West]. Translation from German. SPb., Universitetskaya kniga, $336 \mathrm{s.}$ (Elias N. 1939. Über den Prozeß der Zivilisation. Sozi-ogenetische und psychogenetische 
Untersuchungen. Bd. 1: Wandlungen des Verhaltens in den westlichen Oberschichten des Abendlandes. Basel, Haus zum Falken).

12. Baumann Ch. 2018. Was Hegel an Authoritarian Thinker? Reading Hegel's Philosophy of History on the Basis of his Metaphysics. Forthcoming in Archiv für Geschichte der Philosophie Vol. 2, 2021. (Submitted 11/2017; accepted for publication 9/2018). URL: https://www.academia.edu /38305339/Was_Hegel_an_Authoritarian_Thinker_Reading_Hegels_Philosophy_of_History_on_the_Bas is_of_his_Metaphysics (Accessed 18 of June) 185-198

13. Giladi P. 2017. Hegel, Analytic Philosophy’s Pharmakon. The European Legacy, 22:2,

14. Hegel G.W.F. 1981. Differenz des Fichteschen und Schellingschen Systems der Philosophie in Beziehung auf Reinholds Beytrage zur leichtern Obersicht des Zustands der Philosophie zu Anfang des neunzehnten jahrhunderts. Verlag Philipp Reclam jun. Lepzig

15. Redding Paul. 2010. The Possibility of German Idealism after Analytic Philosophy: McDowell, Brandom and Beyond. Postanalytic and Metacontinental: Crossing Philosophical Divides, ed. Jack Reinolds et al. New York: Continuum, 191-202

16. Redding Paul. 2019. Rethinking Sellars’ Myth of the Given: From the Epistemological to the Modal Relevance of Givenness in Kant and Hegel. International Journal of Philosophical Studies. Volume 27, 2019 - Issue 3: Hegel and Sellars. pp. 379-398

17. Serf W. 1977. Speculative Philosophy and Intellectual Intuition. An Introduction to Hegel's Essays. Hegel G.W.F. Faith \& Knowledge. Translated by W. Serf and H.S. Harris. State University of New York Press, Albany

\section{ИНФОРМАЦИЯ ОБ АВТОРЕ}

Иващук Ольга Федоровна, доктор философских наук, профессор кафедры философии философско-социологического факультета Института общественных наук Российской академии народного хозяйства и госслужбы при Президенте РФ (РАНХиГС)

\section{INFORMATION ABOUT THE AUTHOR}

Olga F. Ivashchuk, Doctor of Philosophy, Professor of the Department of Philosophy and Sociology, Faculty of Philosophy, Institute of Social Sciences, Russian Academy of National Economy and Public Administration under the President of the Russian Federation (RASHP) 